\title{
Resonances arising from Sheltering in the Family Dynamics of Brazilian Women in situations of Violence*
}

\author{
Resonancias derivadas del acogimiento en las dinámicas \\ familiares de mujeres brasileras en situaciones de violencia
}

Enviado: 1o de marzo de 2015 | Revisado: 1o de junio de 2015 | Aceptado: 1o de agosto de 2015

\author{
SCHEILA KRENKEL ** \\ Universidad Federal de Santa Catarina, Brasil \\ Carmen leontina Ojeda Campo Moré \\ Universidad Federal de Santa Catarina, Brasil \\ LeONOR MARía CANTERA EsPinOSA*** \\ Universidad Autónoma de Barcelona, España \\ SABRINA SIlveIRA dE SOUZA JORGE \\ Universidad Federal de Santa Catarina, Brasil \\ Cibele Cunha lima da Motta
}

doi:10.11144/Javeriana.upsy14-4.rdad

Para citar este artículo: Krenkel, S., Moré, C., Cantera, L. M., Silveira, S., \& Cunha, C. Resonances arising from Sheltering in the Family Dynamics of Brazilian Women in situations of Violence. Universitas Psychologica, 14(4), 1245-1258. http://dx.doi. org/10.11144/Javeriana.upsy14-4.rdad

Artículo de investigación. This project was funded by the Brazilian National Council for Scientific and Technological Development (Conselho Nacional de De-senvolvimento Científico e Tecnológico [CNPq])

***carmen.more@ufsc.br

\begin{abstract}
A B S T R A C T
This study aimed to analyze the repercussions of sheltering in the family dynamics of women in situations of violence. This is a qualitative study in which 12 Brazilian women who were given shelter due to have suffered from violence were interviewed. The data organization and analysis was supported by the Grounded Theory, with the help of Atlas.ti software. Before being in the shelter, the study revealed the hardening of family relations and breaking of affectional bonds as well feelings of anxiety, depression, shame, fear and humiliation. Their permanence in the shelter helped the women to create strategies of coping with violence, which in turn, contributed to their reintegration in society as well as the recovery of their dignity and citizenship. Keywords

family violence, intimate partner violence, shelter, community
\end{abstract}

\section{RESUMEN}

Este estudio tuvo como objetivo analizar los efectos del proceso de acogimiento en la dinámica familiar de mujeres brasileñas en situaciones de violencia. Es un estudio cualitativo basado en entrevistas a doce mujeres que sufrieron violencia y que estuvieron en casa de acogida. La organización y el análisis de los datos tuvieron como referencia la teoría fundamentada y el auxilio del software Atlas.ti 7.0. En el período anterior al proceso de acogi$\mathrm{da}$, los resultados mostraron el endurecimiento de las relaciones familiares y la ruptura de lazos afectivos, así como la presencia de ansiedad, estados depresivos, vergüenza, miedo y humillación. El proceso de acogimiento hizo posible la creación de estrategias de afrontamiento al problema de la violencia, promoviendo la reinserción social de las mujeres y el rescate de su dignidad y ciudadanía.

Palabras clave

violencia familiar; violencia en la pareja; casa de acogida; comunidad 
Violence in the family context is characterized by the actions or omissions that undermine the family members' well-being and their physical and psychological integrity or freedom. It also interferes in their development inside or outside home. It can occur between intimate partners, children, women, men, elderlies, including people who assume a parental role, even without ties of consanguinity. Violence is presented by means of aggressive, neglectful, and abusive behavior committed by the family members causing physical and psychological harm and interfering with the development of the other members (WHO, 2002).

This study takes into consideration the family violence in light of the systemic thinking, that is, the recognition of several aspects that contribute to this situation and that are likely to sustain it. Violence within a family is also seen as a paradox, in that the relational dynamics established between the offender and the offended are based on a codependency between affection and aggression, which is expressed through the presence of ambivalent feelings (Ravazzola, 2005). In this sense, the relational dynamics in the family are understood as the way its members organize their bonds, behave based on social rules and standard behaviors, respond to problems and conflicts, establish their rituals, and define the family hierarchy and the roles each member plays within the family (Carter \& McGoldrick, 1995).

Over time, the family system, as an open system and in constant transformation, evolved and with this development there is the presence of vertical and horizontal family stressors. The vertical ones account for those in which the models of relationship and functioning are passed on through generations. With regard to the horizontal ones, there is the anxiety caused by stressors such as pregnancy, marriage, divorce, chronic illnesses, violence and/ or early death (Carter \& McGoldrick, 1995). The boundaries of the families permeated by violence are rigid, that is, people external to the system are prevented from accessing it, which ends up creating difficulties in the communication and the protection of the family members. From this perspective, the existence of such borders allows the establish- ment of the limits and exchanges between the family members, providing them with conditions for the maintenance of their relationships as well as for the acquisition of new skills, both in the relationship with other subsystems (children, for example) and with people outside the family (Minuchin, 1990).

Intimate partner violence can occur through physical harm, psychological control, marital rape, crimes of honor, pimping, and sometimes, the murder of the female partner. According to Dahlberg and Krug (2006), in the 90's, $40 \%$ to $70 \%$ of worldwide homicides against women were committed by their intimate partners. Also, it is assumed that every five days a woman is absent from work, one is due to violence. It is estimated that the deaths of women aged 15-44 due to violence are higher than those by malaria, cancer and traffic accidents and that around $35 \%$ of the cases that come through the health system are connected to intimate partner violence (Dahlberg \& Krug, 2006). In Brazil, it is estimated that every minute, four women are beaten. Between 1980 and 2010, approximately 92,000 women who passed through health services were murdered by their partners or ex-partners (Waiselfisz, 2012).

The data shown depicts the seriousness of violence against women and characterizes it as a major public health problem in the world, which definitely affects the relational dynamics within the family and consequently the vital development of its members (Moré, Santos, \& Krenkel, 2014). This type of violence is presented in a progressive manner, slowly and quietly, and over time, will intensify and be difficult to break (Monteiro \& Souza, 2007). Its progress can be initiated through women's conditions of embarrassment, isolation and humiliation, which later may lead to the occurrence of physical assault, attempts of murder or the murder itself (Moré et al., 2014).

With regard to the advances in relation to the acknowledgment of violence against women within the family context, one of the obstacles still found is the social belief that what happens within the family is a matter that should remain in the private sphere (Cohen, 2013). Historically, according to Scott (1995), relations between men and women 
encompass a social and interactional process in which their roles are constructed and defined according to the presence of values, beliefs, feelings, and behaviors. The author discusses the concept of gender which is understood as a constituent of social relations based on differences between the sexes, identified by power relations socially accepted as natural and unquestionable.

Based on the assumptions present in the patriarchal social system, the roles of men and women are different in the sense that men's dominance prevails in social, community and family relations, giving rise to gender stereotypes (Cantera \& Gamero, 2007). According to the authors, they are understood as generalizations based on impressions about the behavior and characteristics of men and women, limiting their potentialities according to what are meant by appropriate for each gender. Thus, this social construction has granted the power to men and women at different levels, in which men occupies a position of supremacy, while women have a devalued and inferior position. Through violence men show the need to maintain power and control of the situation so that their rules and wishes can be met (Lorente, 2005).

Following the perspective above, with basis on studies of Critical Discourse Analysis (CDA), Fairclough (1989) and Labov (1972) argue that communication among family members is based on a socially constructed discourse that is present in the relational dynamics in the family. The communication supports the ideology that reflects the power relations that define the social roles of each individual (Fairclough 1989; Labov, 1972). According to Freitas (2014), CDA considers "the crucial role of context and the relation between language, power, domination, discrimination and control" ( $p$. 4) which demonstrate, through the analysis of the discourse of social actors, the way this relation of power is built and established.

Regarding the impact of violence against women, studies show loss in their life development, such as anxiety, depression, social isolation, insomnia, fear, post-traumatic stress and impairment of reproductive health (Dahlberg \& Krug, 2006; Moré et al., 2014). Among the social implications and dam- age to the women's health, that is, for their physical, mental and reproductive health, they suffer loss of confidence, abilities, autonomy, values, and fear to control their own lives (Dahlberg \& Krug, 2006). Because of the isolation and the constant state of tension, women also have feelings of uncertainty, helplessness, shame and difficulties to promote change (Moré et al., 2014).

The search for help and strategies to cope with violence can occur when it reaches an extreme situation where there is a threat to women's lives. Coping strategies are the set of cognitive and behavioral efforts used by an individual to manage, reduce, minimize or tolerate stressful situations that exceed their personal resources (Antoniazzi, Dell'Aglio, \& Bandeira, 1998; Faria \& Seidl, 2005; Folkman, Lazarus, Gruen, \& DeLongis, 1986).

In this sense, according to Antoniazzi et al. (1998), coping strategies can be focused on the problem, emotions and interpersonal relationships. The first one refers to the attempt to change the situation and/or the problem that causes the stress by asking for help (money or a place to live), by seeking information and by acting in order to solve the problem. The second one relates to emotionfocused strategies and acts aimed at regulating the emotional state and reducing the unpleasant feeling of tension associated with stress. These feelings are manifested by crying, overeating, the indiscriminate use of cigarettes, taking tranquilizers, watching a movie or doing physical activity. The third coping strategy is focused on interpersonal relationships, in which the individual seeks support for coping and solving the problem by engaging those that make up their network of relationships (Antoniazzi et al., 1998).

Women in situations of violence seek help in their relationship networks or networks of social assistance. The social assistance networks are formed by formal institutions and organizations committed to cope with violence. Their practices are engaged in the prevention and promotion of health of the individual in the community through hospitals, health centers, police departments, social services and shelters. Such actions help the decrease of stress 
and the increase of well-being (Campos, 2005; Moré et al., 2014).

Among the sheltering institutions for women in situations of violence, there are the women's shelters. They are entitled to ensure assistance and protection of the physical and psychological integrity of women and their minor children who are in imminent risk of death (Brasil, 2006). In Brazil, women's shelters are institutional places economically maintained by the city councils which also include resources from the Federal Government (Brasil, 2006).

Women in situations of violence are sent to these shelters by protection agencies or by the police when they find their lives are at risk. The time women spend in these shelters varies according to each case, depending on the psychological and safety conditions they are provided with in order to be reintegrated in society (Brasil, 2006). Women's shelters are considered an important feature in the support network to cope with violence, since it provides security and teams of professionals that promote care and support for women, additionally allowing moments for them to reflect upon their lives and helping them to create strategies to address the problem of violence (Rocha, 2007).

In Brazil, there are 77 women's shelters in 26 states as well as in the Federal District (Brasil, 2006). This research was developed in South of Brazil, a region with three states: Paraná, Santa Catarina and Rio Grande do Sul. This region has a population of approximately $28,700,000$ people, among which $48 \%$ are females (IBGE, 2014). They are mostly Caucasians $(78,5 \%)$ derived from a process of miscegenation of immigrants from Italy, Portugal, Germany, and Japan as opposed to the other regions in the country in which the predominance is Afro-Americans. The South has the highest socioeconomic index in the country, a high per capita income, life expectancy of 75 years old, low rate of infant mortality and illiteracy (IBGE, 2014). In this region there are only 18 shelters for women in situations of violence (Brasil, 2006) and the homicide rate of women is 4.6 out of 100,000 people (Waiselfisz, 2012). In particular, the women's homicide rate in the state of Espírito Santo is 9.8, the highest of all. With regard to it, it gets clear the need for the establishment of more women's shelters or similar places that can offer protection to women victims of violence.

According to what was mentioned above, this study aims to analyze the repercussions of the process of sheltering on the relational dynamics of the families of women in situations of violence. For this, it relies on the Systemic Thinking, in which the individual, the family and the society are considered a whole unit, instead of individual parts. Thinking systemically means to understand the phenomena within their own context of situation and the dynamic process of the relationships, in which different realities are created according to the way people interact with themselves and with the world (Vasconcellos, 2009). More specifically, the Systemic Thinking takes into account the interrelation among the individuals in the phenomenon of violence. Within this perspective, violence is seen as a relational phenomenon, in which all its participants contribute for its maintenance within the family context regardless of the responsibility of the perpetrator.

The relevance of this scientific study, in face of the small number of studies in the area, is due to the necessity of investigating the efficacy of the women's shelters in regard to the service provided. The focus of this study is to reflect upon the improvement of the public policies to cope with violence against women as well as on the professional practices found in women's shelters. Also, it is to develop appropriate and strategic assistance that may help to intervene in the family violence cycle.

\section{Method}

\section{Participants}

This is a qualitative study of interviews with 12 women in Brazil who have experienced violence in the family context and were welcomed into a women's shelter. The criteria for the choice of the participants in this study were: a) being over 18 years; b) having experienced family violence; c) having stayed at the women's shelter during the 
years 2012 and 2013; d) having remained in the women's shelter for at least 10 days; e) having lived in the county where the women's shelter is located. Socio-demographic characteristics of the participants can be seen in Table 1 .

\section{Procedure for Data Collection and Analysis}

The data collection started with a survey of the names of 64 women who met the criteria for the study. Out of this number, it was possible to reach only 14 women. As for the other women, either they did not have their phone number registered by the Secretary of Social Assistance or their phone numbers were shown incorrect. Telephone contact was made initially by professional workers (social workers and psychologists) of the Department of
Social Welfare, who introduced the researcher to these women. After that, they passed the call to one of the researchers, who introduced herself again, explained to the women the purpose of the research and invited them to participate in it. It was possible to reach only 14 women, all of whom, at first, agreed to participate. However, two of them did not appear for the appointment, resulting in a total of 12 participants. The data collection took place at the Secretary of Social Assistance, and was scheduled according to the availability of the women. All interviews were recorded and transcribed for later analysis. The interview questions consisted of matters related to socio-demographic aspects, women's relationship with the perpetrator of the violence, the impact of violence, and the coping strategies used.

TABLE 1.

Socio-demographic characteristics of women

\begin{tabular}{|c|c|c|c|c|c|c|c|}
\hline \multirow[b]{2}{*}{ Participants } & \multicolumn{7}{|c|}{ Socio-demographic data } \\
\hline & Age & $\begin{array}{l}\text { Marital } \\
\text { Status }\end{array}$ & $\begin{array}{l}\text { Total of } \\
\text { children }\end{array}$ & $\begin{array}{l}\text { Educational } \\
\text { level }\end{array}$ & Occupation & $\begin{array}{l}\text { Family } \\
\text { Income }\end{array}$ & $\begin{array}{c}\text { Time at } \\
\text { women's shelter }\end{array}$ \\
\hline P1 & 68 & Widowed & 8 & $\begin{array}{l}\text { Elementary } \\
\text { Incomplete }\end{array}$ & Retired & $\$ 833,00$ & 21 days \\
\hline P2 & 21 & Separated & 1 & $\begin{array}{l}\text { High School } \\
\text { Complete }\end{array}$ & Production Assistant & $\$ 409,00$ & 36 days \\
\hline P3 & 27 & Married & 4 & $\begin{array}{l}\text { Elementary } \\
\text { Incomplete }\end{array}$ & General Services & $\$ 833,00$ & 42 days \\
\hline P4 & 43 & Separated & 3 & $\begin{array}{l}\text { Elementary } \\
\text { Complete }\end{array}$ & Retired on Disability & $\$ 368,00$ & 53 days \\
\hline P5 & 32 & Separated & 2 & $\begin{array}{l}\text { High School } \\
\text { Complete }\end{array}$ & Call Center operator & $\$ 327,00$ & 12 days \\
\hline P6 & 22 & Married & 4 & $\begin{array}{l}\text { Elementary } \\
\text { Incomplete }\end{array}$ & $\begin{array}{l}\text { Textile Industry } \\
\text { Assistant }\end{array}$ & $\$ 778,00$ & 117 days \\
\hline P7 & 31 & Separated & None & $\begin{array}{l}\text { High School } \\
\text { Complete }\end{array}$ & Unemployed & $\$ 122,00$ & 30 days \\
\hline P8 & 23 & Married & 4 & $\begin{array}{l}\text { High School } \\
\text { Complete }\end{array}$ & General Services & $\$ 416,00$ & 15 days \\
\hline P9 & 31 & Married & 2 & $\begin{array}{l}\text { Elementary } \\
\text { Incomplete }\end{array}$ & General Services & $\$ 900,00$ & 22 days \\
\hline $\mathrm{P} 10$ & 34 & Separated & 3 & $\begin{array}{l}\text { Elementary } \\
\text { Complete }\end{array}$ & Cleaner & $\$ 277,00$ & 17 days \\
\hline P11 & 39 & Married & 2 & $\begin{array}{l}\text { Elementary } \\
\text { Incomplete }\end{array}$ & Unemployed & $\$ 696,00$ & 30 days \\
\hline $\mathrm{P} 12$ & 22 & Separated & 2 & $\begin{array}{l}\text { High School } \\
\text { Incomplete }\end{array}$ & Trainee & $\$ 286,00$ & 28 days \\
\hline
\end{tabular}

Source: own work

Obs.: The values presented in the item 'family income' refer to US dollars. 
The organization and analysis of data were based on the Grounded Theory proposed by Strauss and Corbin (2008). This study, as part of a greater research, is supported by the Grounded Theory, which is considered a reference in the integration of data derived from several sources. It also enables the construction of a theory that derives from the collected data. In order to facilitate the process of organizing, processing, and analysis of qualitative data, the Atlas.ti 5.0 program was used, which helped in the construction of categories, by establishing relationships and connections between the data (Muhr, 2004). The data was integrated and systematized according to the proposal for analysis by codification: open, axial and selective (Strauss \& Corbin, 2008).

In the Open Codification, there was the identification of the elements and their ordinary and similar aspects as well as the divergent characteristics between the obtained data, which helped in the assembly of the elements, creating preliminary categories of analysis. The Axial Codification occurred from the reassembly of the identified elements in the Open Codification. In this type of codification, the relation between the categories and the sub categories of analysis, according to their specificities, was made possible. Finally, the Selective Codification allowed the integration and refining of data, in which it was possible to relate the subcategories and elements of analysis that sustained the main categories. The data was organized into two categories of analysis and their respective categories, that aimed to reach the purpose of this research. They are: 1) The characteristics of family dynamics before sheltering: a) The trigger points of violence; $b$ ) The permanence with the perpetrator of violence, c) The emotional consequences of violence; 2) The elaboration of strategies for coping with violence during sheltering: a) The search for a social assistance network; b) The experience of sheltering as an opportunity to create and strengthen coping strategies; c) The possibility of reformulating their life plans.

\section{Ethical Considerations}

This study was approved by the Ethics Committee in Research with human beings at the Federal Uni- versity of Santa Catarina (Brazil), by the approval number 251,240, and met the ethical requirements based on Resolution 466/2012 of the National Health Council.

\section{Results}

The results gathered elements related to the characteristics of relational dynamics of families of women before going to the shelters and emotional consequences of violence. Furthermore, it shows the repercussions of their experience in the women's shelter with respect to their strategies used for coping violence.

\section{1) The characteristics of the family dynamics before sheltering}

The results gathered elements related to the characteristics of relational dynamics of the women's families before going to the shelters. This category has three subcategories which reflect the reasons why violence between the participants and their partners occurred, the aspects which contributed to the permanence of the women in violence and the emotional consequences for the women's health derived from violence.

\section{a) The trigger points for violence}

This category has assembled a set of elements indicated by the participants as what they believed to be the reasons that contributed to the outbreak of the episodes of violence. The partner's violent behavior was related to a disease or disorder, argued by the participants as a possible explanation and/or justification for the occurrence of violence. According to the narratives, the violent behavior was related to some kind of pathology, personality disorder, or to the "character of the person" (sic). Jealousy and suspicion of betrayal by their partners were also mentioned. In addition to that, the partner's use of alcohol and other drugs were considered precursors of the early episodes of violence.

The participants also mentioned that the offenders did not think before speaking or about the 
feelings of those who were listening to the offenses, characterizing them as individuals acting by impulsivity. In addition, the participants made reference to their partners' sexist behavior reflected by their abuse of authority, the lack of dialogue between them, and their refusal of the participant's willingness to work or study as means of achieving their autonomy:

The first thing he did when we decided to move in together was to deprive me of continuing my studies. The first thing he asked me was for me to stop studying. [...] And we began the conflict when I decided to start working even against his will. Then he started getting more aggressive as I became more independent (Participant 2).

With respect to the outbreak of violence, the participants pointed out the following aspects: their period of pregnancy, the born of the first child and the fact they had small children, as seen in the narrative below:

I was constantly beaten up when I was pregnant. I often had to run away to avoid being stabbed by my husband. I ran with my pregnant belly, with a little child and another baby in my arms. I had one baby after the other (Participant 1).

The participants reported a desire to separate from their partners because of the situation of violence they were experiencing, but the partners did not accept that. Therefore, their refusal is an aspect identified as trigger of violence. According to the participants, the attempts of a relationship break up contributed to new as well as repeated episodes of violence.

\section{b) The permanence with the perpetrator of violence}

All the elements within this category described the reasons by which the participants kept a relationship with their partners. Among them, there was their belief in their partners' possible change of behavior, which was signaled through compensatory actions such as flowers and gifts, apologies, love vowels and promises that violence acts would never happen again. The participants also mentioned that they remained with their partners longer because they considered it to be important to keep their marriage and family togetherness. In this regard, the narratives of the participants were based on cultural and religious aspects present throughout their development. Interestingly, they held the belief that marriage is for life and that family should stay together regardless of what happens.

In addition to this, the participants argued that they felt emotionally involved in the relationship. According to their reports, despite of the episodes of violence and apologies from the partner, they took into consideration their positive character traits, such as being a good parent, a hard worker, and a good person when they were not on the effect of alcohol or did not have a violent behavior. "And actually, I kept thinking how I would do this [to report] with the father of my child. A person I lived with for so many years" (Participant 2). With regard to these aspects, we found that the participants had ambivalent feelings characterized by love and hate, hope and fear, which made them to give another chance to their partners, as the women believed their partners were going to change and stop with the offenses. These factors contributed to the postponing of the reporting of violence acts and consequently, to their permanence in that situation.

So, while he was my companion he was also my friend. He was good and bad to me. He was the person who loved me the most, who made me feel good the most, but at the same time he was the worst person in my life. So it was a great disappointment. (Participant 7)

In addition to this, there are other aspects about the permanence in the situation of violence that should be referred to. They are the social isolation of the participants, the lack of assistance at social networks with which they could rely for help as well as their unawareness about the resources that could facilitate the breaking of the cycle of violence, such as police departments and any type of social assistance. 


\section{c) The emotional consequences of violence}

This subcategory showed elements about the reactions and emotional consequences to the participants' health derived from the situation of violence. The participants reported to have felt depression symptoms and have used medication to treat anxiety. One of the participants mentioned to have attempted suicide as a way of eliminating suffering:

Actually, I was feeling hopeless. I tried to kill myself twice. I thought I did not know where to go [...] if I live another thirty years it will always be like this. So I had moments of desperation. I tried it twice. I took a lot of medicine to die because I could not find a way out (Participant 4).

The participants also reported feelings of sadness, loneliness, pain, anger, hatred and bitterness. Together with these emotions, they also claimed to feel shame and humiliation caused by their partners, especially in the social sphere, as well as the feeling of impotence towards that situation: "I felt humiliated, you know. Actually, I felt like nothing [...] when facing a situation of violence, you end up feeling you are alone, vulnerable. When you live with violence, you live without protection" (Participant 8). In face of this, there is also the participants' feeling of loneliness as a result of rejection from people of their community, which helped the participants to avoid reacting to violence.

During the interviews, the participants also reported to be afraid of the threats and perpetrations of violence and of losing their children's custody as well as their own lives: "I was afraid of not seeing my son to grow up, in fact, I was afraid of being killed by my ex-partner" (Participant 2). The main fear that the participants referred to was the fear of death, as they were afraid that their partners or expartners would fulfill the promises they had made when they were together. It is worth mentioning that the death threats and attempts by their partners kept happening even after women had left the women's shelter. In turn, this situation helped them to maintain the feeling of fear due to their feeling of being oppressed by their partners.
The participants in this study are women in situations of several types of violence (physical, psychological and sexual) as well as several attempted murders by their partners. According to them, when violence became unbearable and their lives were at risk, they required help in order to cope with the situation.

\section{2) The elaboration of strategies for coping with violence during sheltering}

This category joined a number of elements about the elaboration of strategies for coping with violence which was favored by the situation of sheltering, thus contributing to the reestablishment of the women's life plans as long as they were reintegrated in society. This way, this category is composed by three subcategories: a) the search for social assistance network; b) the experience of sheltering as an opportunity, creation and strengthening of coping strategies; c) the possibility of reestablishing their life plan.

\section{a) The search for a social assistance network}

In this subcategory, the search for a social assistance network was the beginning of the breaking process as well as the beginning of the strategies for coping with the situation. Other institutions where women went to search for help are: police departments (including those who are specialized in women's assistance) health units and the secretary of social assistance. When violence also happened against the children, there were other institutions engaged in aiming to solve the problem, such as schools and children's council.

As the participants' lives were at risk due to death threats and attempted murders, the institutions they asked for support became engaged in finding them and their children a shelter. Out of all the institutions they went to, the ones which sent them straight to the shelter were the police departments specialized in dealing with cases of violence against women, (called in Portuguese DEAM) and the Secretary of Social Assistance. Noteworthy, all the institutions in charge of providing assistance 
to them could have sent them to sheltering, as the perpetrator of violence confessed the offense to the police.

\section{b) The experience of sheltering as an opportunity of creating and strengthening coping strategies}

This subcategory joined elements related to coping strategies strengthened and/or created by the participants in this study while they were in the shelter. According to them, the procedures taken by the shelters professional workers at the shelters (psychologists, social assistants, social educators) contributed for the women's senses of empowerment and rewarding, by which they became confident about the possibility of living their lives away from violence, as it is reported below:

I believe that it was worth it being away, as I could realize that I do not need to be spanked and being in the shelters made me think how good it could be if life was not only spanking (Participant 12)

Moreover, they mentioned that the women's shelter made them feel protected and secure and provide them moments to rethink about the situation of violence. The participants also claimed that being in the shelters made them changed in the sense they were able to take actions and to become more confident to cope with violence.

\section{c) The possibility of reformulating their life plans}

This subcategory put together elements which reflect the women's strengthening and elaboration of strategies for coping with violence based on their sheltering experience in the shelters. The following strategies contributed for the reformulating of the women's life plans which were prevented from being executed due to the situation of violence they were found in. The participants also mentioned about their relation with the shelter professional workers, who offered them constant emotional support and helped them to find job and a place to live in order for them to have an income as well as a place to live after they left the shelters. They claimed that having an occupation (a job) and/or getting back to studies were measures responsible for them being able to cope with violence. The possibility to have a new job or to get back to work were aspects considered very important by the participants as they enabled them to go out from home, to have fun, to have contact with other people, to have autonomy and to feel useful.

Among the repercussion as much for their passages in the women's shelter as for their coping with violence after leaving it, they pointed out as important the psychological assistance they received, as they believe this action contributes for the emotional exteriorization. Likewise, they also mention the religious practice such as having faith, praying and believing in God and the search for friends to talk about their problems or just 'to forget' about them by raising issues that helped them not to think about the situation of violence they were in and the consequences of it. Other measures used to cope with violence were also mentioned: The practice of sports (walking, soccer), watching films, reading and listening to music. All these coping strategies started after the participants had left the shelter. They pointed out that the time they spent there was crucial for them to become reintegrated in society as they were encouraged to recover their autonomy as well as to reestablish their life plans based on the opportunity of getting a (new) job and returning to study.

\section{Discussion}

This study focused on the analysis of the repercussions of sheltering in the family dynamics of women in situation of violence. From the analysis of data gathered in the two categories listed above, and their respective subcategories, it is possible to be aware of the experiences of the participants of this study in relation to the situation of violence as well as the repercussions of their passage in the shelters.

With regard to the characteristics of the family dynamics before being sheltered, the trigger points of violence were jealousy, distrust, betrayal and abuse of alcohol and other drugs. The existence of a disease or disorder was mentioned by the partici- 
pants as a possible explanation and/or justification for the occurrence of violence. This is attributed to the fact that they did not see any other reasons for violence to happen other than those related to some sort of pathology or personality disorder (character). Aspects of personality, including irritability, intolerance to stress, frustration and impulsivity were pointed out by the participants of this study. These aspects corroborate the assumptions made by Cantera and Gamero (2007) in studies that traced the profile of the perpetrator of the violence. The characteristics listed above may be considered as a means of justifying the episodes of violence which, in turn, may contribute as a 'trap' for the permanence of the participants in the relationship.

The results of this study also showed that episodes of violence were present at different stages of the life cycle of the family, such as pregnancy, family with young children, couple separation and the attempt of it, all of which seen as horizontal stressors. The increase of tension between the couple towards their new roles and responsibilities in relation to their children may result in fights, family conflicts and neglect (Carter \& McGoldrick, 1995). According to the authors, this means that family stressors present in the transitions of the different stages of the life cycle are generators of symptoms and disorders and that the new challenges that these stages demand can unleash violent behavior within the dynamic of the family.

The results of this study also show the presence of men's sexist discourse and the use of physical force by the perpetration of violence as a way to keep the women quiet and prevent them from leaving home (to separate). By relating these aspects to the characteristics of the patriarchal system, which prevails in the physical domination and decision of a man, it is possible to think that when the 'disobedience' of women occurs, some men feel entitled to attack them as a way of reasserting their power and authority role in the relationship (Cantera \& Gamero, 2007; Scott, 1995). In this sense, it is relevant to discuss the consensus, among all the participants, of the physical and the verbal domination of men which, according to Fairclough (1989) and Freitas (2014), is found within the family established by a discourse embedded by ideologies that reflect power relations which define social individuals and their roles. Thus, it is believed that the discourse produced by the partners in a relationship makes evident the naturalization of certain ideologies and how they have been accepted as common sense that reproduce social power through discourse (Fairclough, 1989; Labov, 1972).

Based on this understanding, we can mention men's discourse in a conjugal relationship of conflict as one that corroborates the traditional 'sexist' discourse, elaborated and accepted by a segment of society that shares the same ideologies which, in turn, places men in a position of power and control over women. In this sense, with basis on the characteristics of the patriarchal system, the belief that men has the power and control over women appears present in the women's stories also when they refer to the search for autonomy (to work and to study) as a reaction to the early episodes of violence.

These aspects relate to attitudes toward the maintenance of power, in which the man will progressively adopt controlling and violent behavior in order to establish limits to the women (Lorente, 2005). It is considered that this kind of behavior of men as perpetrators of violence, over time, will gradually condition women according to their partners' interests and needs. At this point, women feel unable to change their own reality as they fear retaliation from their partners, and this is one of the aspects which end up supporting their permanence and subjection of the woman in the relationship.

With regard to women's permanence in the relationship with a perpetrator of violence, some participants reported a desire to follow the family standards of life such as keeping the marriage until the end of life and/or not separating from their partners due to religious beliefs about marriage. Studies show that in cases where the woman decides to keep the relationship with the partner, the fatherhood, their fear of being alone and their family values may have more impact than the act of violence itself (Cohen, 2013; Othman, Goddard, \& Piterman, 2014; Moré et al., 2014).

Likewise, the participants mentioned ambivalent feelings about the perpetrator of the violence, 
such as love and disappointment, hope and fear, especially when considering positive traits of their partners even after recurrent episodes of violence. According to Ravazzola (2005), the enhancement of the partner's positive characteristics refers to 'relational anesthetics', which are present in marital relations and appear in opposition to the expected reaction from people facing or experiencing violence in their daily lives. The permanence in the affectional relationship is due to social expectancies, values and beliefs about a relationship as well as to the positive characteristics of their partners, which surpasses the experiences of violence and, as a result, keeps women in the type of anesthesia status. The expected response of people who have contact with a situation of social or family violence - either as a witness or as directly involved in it - is to feel pain, outrage, anger, helplessness and shame. The experience of malaise would lead to some kind of reaction in order to stop it and the presence of this 'anesthesia' would prevent this to happen.

Women in situations of violence live a reality that neither corresponds to the way they are treated nor to the romantic love they imagine to be possible and to an expected reciprocity by their partners (Ravazzola, 2005). As they cannot see or do not perceive the recurrence of violent behaviors, the women become totally unaware of the real meaning of violence and the harmful consequences of it. Thus, there is the hope that each episode of violence is considered the last one, as promised by their companions. As this does not occur, the boundaries of the family system to which these women belong become increasingly stiff over time, preventing or hindering them to pursue or receive any type of assistance which, in turn, keeps them in the situation of violence. Their permanence in a system with such rigid borders may contribute to the increasing of acts of violence through the attempted murder, as it happened with all the participants in this study.

Emotional consequences of violence left visible and invisible marks. The former relates to physical violence and the latter, to feelings of anxiety and depression as main symptoms of psychological distress, and feelings of shame, fear and humiliation.
Women in an inferior position to which they are subjected to by her partner can be tied to a set of other feelings that make them feel humiliated and ashamed, and fearing for their lives, their families' and friends. Humiliation and shame may be also related to the women's beliefs about the reasons why they allow themselves to experience violence and cannot get out of it.

Therefore, issues like fear, lack of information, and the belief that the partner is not such a bad person as he appears to be, make women minimize the gravity of the situation, preventing the violence from leaving the private sphere and then, from becoming public (Monteiro \& Souza, 2007). This reality raises the need to break with the traditions and social meanings constructed around the acceptance of violence in the family as a natural behavior (Cohen, 2013). Cantera and Gamero (2007), argue that the duration and intensity of the effects of violence will depend on the severity of the trauma, the social and institutional support received, and the resources used by women to combat violence.

Accordingly, with regard to the appearance of coping strategies in situations of violence, the participants found personal resources and access to institutions that enabled them to cope and/or withdraw from the cycle of violence. Coping strategies are directly linked to one's life experience, based on their individual characteristics, their culture, beliefs, and personal values (Folkman et al., 1986). Corroborating this view, Moré, et al. (2014) argue that women who live in a situation of violence make use, intentionally or not, of coping strategies either to survive or to overcome the consequences of that relationship.

The search for psychological help, the police and social services composed the problem-focused strategies, which led the participants to the women's shelter and to have psychological assistance which began right after they left it. For the participants, talking about violence and the ways to overcome it were considered important factors in addressing the problem. For the participants, their permanence in the shelter provided them with the chance to reflect on their lives and rethink of certain behaviors that could be modified in the future. Moreover, the 
shelters also contributed to the empowerment of the women, to the rescuing of their dignity and to the potentiality in the search for strategies to cope with the problem. Within this context, it is worth mentioning the dedication of the professional workers at the shelter with regard to lodging the women, listening to them and watching out for their security and mental health.

Furthermore, the assistance provided by the professional workers in the shelter, such as help for searching for a job and a place to live, facilitated the social reinsertion of the participants, based on their life plans and which involve the beginning of a new job and getting back to studies. This way, the professional workers at the women's shelter helped with the recovery of the potentialities of the participants, supporting them in the search for coping with strategies for violence. As noted in the study by Rocha (2007), women's shelter is a place where women can strengthen and regain their ability to have peace. The shelter worked as a network of social support, contributing to the promotion of the women's health, by fulfilling functions both emotionally and materially in order to reduce stress as well as the increase of women's well-being (Campos, 2005).

In the study, it was observed that the actions taken in the shelter also contributed to the establishment of its effectiveness as a sheltering institution where women could reflect upon their lives plans and develop coping strategies for violence, even after they had left the place. Coping strategies focused on emotion account for the search for the regulation of emotional state and decrease of unpleasant situations aroused at the time of experienced stress (Antoniazzi et al., 1998). Religiosity appears as a way to achieve this emotional balance as it is related to beliefs which are part of a personal value system, that is, it is related to the way each person deals with a stressful situation. However, religiosity is not seen as a means of trying to find the cure to the problems, but as a way to promote individuals' well-being and commitment to find a solution (Faria \& Seidl, 2005). The same occurs in relation to work and school activities selected by women as pleasurable activities, which made them feel good and contributed to the increase of self-esteem whenever they found themselves in situations of violence.

It was observed, with less frequency, that coping strategies were also focused on interpersonal relationships. In this case, it was mentioned that the search for friends was helpful, especially because the participants found people to talk to, developed joint activities, and received emotional support. The contact with people in relationship networks is important in that it generates self-esteem and confidence, and helps in reducing the stress created by the problem of violence (Moré et al., 2014). According to Estrada, Herrero and Rodríguez (2012), friends offer greater emotional support to those in situations of violence, and the demand for them may be related to a decrease or lack of support from family members. The authors point out that, in some way, searching for friends reveals the decision of women to bring violence into the public sphere, while it shows the importance of friendship for addressing violence situations.

Given this, it is worth mentioning that most of the strategies mentioned by participants in this study occurred after leaving the women's shelter, more specifically, after the violence reached a limit in which institutional action was essential to protect the women's lives. The delay of seeking for help may be due to the oppression of the participants in the situation of violence according to the reasons that made them remain in the relationship, such as the feeling of fear or shame, or to their unawareness of personal and institutional resources. Thus, it is assumed that the feeling of oppression coupled with a lack of networks of personal relationships and social support impairs visibility as well as the search for resources that can help them out of the situation of violence. Moreover, the lack of women's attitude along with the absence of networks of personal relations and assistance are seen as constraints for the viability and search for resources that can help them to cope with violence.

This study, in turn, was able to show that contact with those outside of the family system, characterized by the demand for the intervention of friends and professionals at the women's shelter, 
allowed them to break the boundaries of the violence routine in the family. In this sense, the importance of the presence of networks of relationships and/or institutional support for the hosting, care, and protection of the lives of these women's lives is made relevant.

\section{Final considerations}

The participants in this study were women who experienced extreme violence, such as threats and attempts of murder perpetrated by their partners, which led them to seek for help and to take refuge in a women's shelter so that they could stay alive. The analysis of data collection revealed facts that usually remain hidden by the silence of the participants due to fear, guilt, helplessness, humiliation and/or embarrassment in talking about it, bringing out aspects that are present in women living in situations of violence.

Based on the data collected in this study, the hardening of the family relations and the rupture of the bonds with the networks of reference contribute to the permanence of these women in the situations of violence. This can happen for both their social isolation as well as the obscurity for finding resources to leave their condition as subjects of violence. In this study, the shelter was essential in order to help the participants to cope with the situation, by allowing them to reestablish their affectional bonds, by means of reflection about their own experience. The women's shelter is also seen as an important resource among many others that may contribute for the life protection of women in situations of violence as well for the recovery of their dignity and citizenship. This makes evident both its potentiality as a sheltering institution that is engaged in the protection of women's lives as well as the need for the creation of new women's shelters in Brazil, with focus on their social integration.

Due to Brazilian economic, racial and cultural differences, a study of women's shelters in other states in the country is made necessary. This will enable us to see how the professional practices in other shelters occur and how women are reintegrated in society afterwards. The results of the present study contribute to a reflection upon the establishment and improvement of sheltering and intervention strategies, as well the establishment of public policies which are engaged in the promotion of health and of the right of citizenship of the women and their family members in situations of violence.

\section{References}

Antoniazzi, A. S., Dell'Aglio, D. D., \& Bandeira, D. R. (1998). O conceito de coping: Uma revisão teórica. Estudos de Psicologia, 3(2), 273-294.

Brasil, Secretaria Especial de Políticas para as Mulheres, SPM. (2006). Termo de Referência: Apoio a casas abrigo e centros de referência. Brasília, DF: SPM.

Campos, E. P. (2005). Quem cuida do cuidador. Uma proposta para os profissionais da saúde. Rio de Janeiro: Vozes.

Cantera, L. M., \& Gamero, V. (2007). La violência en la pareja a la luz de los esteriotipos de género. Psico PUC, 38(3), 233-237.

Carter, B., \& McGoldrick, M. (1995). As mudanças no ciclo de vida familiar - uma estrutura para a terapia familiar. Porto Alegre: Artes Médicas.

Cohen, S. C. (2013). Mujeres maltratadas em la actualidad: Apuntes desde la clínica y diagnóstico. Buenos Aires: Paidós.

Dahlberg, L. L., \& Krug, E. G. (2006). Violência: Um problema global de saúde pública. Ciência Saúde Coletiva, 11(Sup), 1163-1178.

Estrada, C., Herrero, J., \& Rodríguez, F. J. (2012). La red de apoyo em mujeres víctimas de violencia contra la pareja em el estado de Jalisco (México). Universitas Psychologica, 11(2), 523-534.

Fairlough, N. (1989). Language and Power. Harlow: Longman Group UK.

Faria, J. B., \& Seidl, E. M. F. (2005). Religiosidade e enfrentamento em contextos de saúde e doença: Revisão de literatura. Psicologia: Reflexão e Crítica, 18(3), 381-389.

Folkman, S., Lazarus, R.S., Gruen, R. J., \& DeLongis, A. (1986). Appraisal, coping, health status, and psychological symptoms. Journal of Personality and Social Psychology, 50(3), 571-579.

Freitas, L. G. (2014). Argumentation and Discourse on the Maria da Penha Act in Decisions of the 
Brazilian Superior Court of Justice. Rev. Estud. Discurso, 9(1), 71-89.

Instituto Brasileiro de Geografia e Estatística, IBGE. (2014). Estimativas populacionais para os municípios brasileiros em 01.07.2014. Rio de Janeiro, RJ: IBGE.

Labov, W. (1972). Sociolinguistic Patterns. Philadelphia: University of Pennsylvania Press.

Lorente, M. L. (2005). Anatomía del maltratador. La violência como mecanismo de control. In L. M. Cantera (Org.). La violencia a casa (pp.). Sabadell: Fundació Caixa de Sabadell.

Minuchin, S. (1990). Famílias, funcionamento e tratamento. Porto Alegre: ArtMed.

Monteiro, C. F. S., \& Souza, I. E. O. (2007). Vivência da violência conjugal: Fatos do cotidiano. Texto $\mathbb{E}$ Contexto - Enfermagem, 16(1), 26-31.

Moré, C; L. O. O, Santos, A. C. W., \& Krenkel, S. (2014). A rede social significativa de mulheres que denunciaram a violência sofrida no contexto familiar. In R. M. S., Macedo (Org.). Família e comunidade: Pesquisa em diferentes contextos (pp.). Curitiba: Juruá.

Muhr, T. (2004). ATLAS/ti the knowledge workbench. V 5.0 Quick tour for beginners. Berlin: Scientific Software Development.
Othman, S., Goddard, C., \& Piterman, L. (2014). Victims' Barriers to discussing domestic violence in clinical consultations: A qualitative enquiry. Journal of Interpersonal Violence, 29(8), 1497-1513.

Ravazzola, M. C. (2005). Historias infames: Los maltratos em las relaciones. Buenos Aires: Ed. Paidós.

Rocha, L. M. L. N. (2007). Casas-abrigo no enfrentamento da violência de gênero. São Paulo: Veras Editora.

Scott, J. W. (1995). Gênero: Uma categoria útil de análise histórica. Educação E̊ Realidade, 20(2), 71-99.

Strauss, A., \& Corbin, J. (2008). Pesquisa qualitativa: Técnicas e procedimentos para o desenvolvimento de teoria fundamentada. Porto Alegre: Artmed.

Vasconcellos, M. J. E. (2009). Pensamento sistêmico - O novo paradigma da ciência. 8a Ed. Campinas, SP: Papirus.

Waiselfisz, J. J. (2012). Mapa da violência 2012 Atualização: Homicídios de mulheres no Brasil. Rio de Janeiro: Centro Brasileiro de Estudos LatinoAmericanos.

World Health Organization - WHO. (2002). World report on violence and health. Geneve: World Health Organization. 